Check for updates

\section{London}

Cite this as: $B M J 2020 ; 369: m 2330$ http://dx.doi.org/10.1136/bmj.m2330 Published: 11 June 2020

\title{
Covid-19: Appropriate PPE prevents infections in doctors in frontline roles, study shows
}

\section{Ingrid Torjesen}

Provision of appropriate personal protective equipment (PPE) and training does protect doctors treating covid-19 patients from exposure to the infection, a study published in The BMJ has confirmed. ${ }^{1}$

The study focused on a group of healthcare workers deployed to Wuhan from other regions of China to treat covid-19 patients as the epidemic took hold. All were provided with and trained in the use of PPE, and none developed symptoms of covid-19 or later showed antibodies to the virus.

At the outset of the epidemic in Wuhan little was known about the infection and what PPE was needed to protect against it. As a result many doctors and other healthcare workers were infected, and some died. As cases surged, healthcare workers were drafted in from other regions of China and were provided with PPE and trained in its use.

Researchers from Sun Yat-sen University in China and the University of Birmingham, UK, tracked a group of 116 doctors and 304 nurses deployed to Wuhan for 6-8 weeks from 24 January to 7 April 2020.

The group worked 4-6 hour shifts for an average of 5.4 days a week, and each spent an average of 16.2 hours each week in intensive care units. All were provided with appropriate PPE including protective suits, masks, gloves, goggles, face shields, and gowns, and they were trained in how to use them correctly and how to reduce their exposure to infection when caring for patients. All had direct contact with patients with covid-19 and performed at least one aerosol generating procedure.

\section{Negative tests}

During their deployment in Wuhan none of the doctors and nurses reported any covid-19 related symptoms, and when they returned home they all tested negative for covid-19 infection or its antibodies.

"Despite being at high risk of exposure, study participants were appropriately protected and did not contract infection or develop protective immunity against SARS-CoV-2," the researchers concluded.

"Before a safe and effective vaccine becomes available, healthcare professionals remain susceptible to covid-19," they added. "Healthcare systems must give priority to the procurement and distribution of personal protective equipment, and provide adequate training to healthcare professionals in its use."

They pointed out that the study did not look at the minimal level of PPE needed to effectively prevent infection among healthcare professionals, and they said that the findings applied only to frontline clinical staff.

In the UK, doctors have launched judicial review proceedings after the government decided not to open an inquiry into failures to provide adequate PPE for frontline workers. ${ }^{2}$

1 Liu M, Cheng S-Z, Xu K-W, etal. Use of personal protective equipment against coronavirus disease 2019 by healthcare professionals in Wuhan, China: cross sectional study. BMJ2020;369:m2195doi: 10.1136/bmj.m2195.

2 Rimmer A. Covid-19: Doctors launch judicial review over PPE failures. BMJ 2020;369:m2301. doi: 10.1136/bmj.m2301 pmid: 32518089

This article is made freely available for use in accordance with BMJ's website terms and conditions for the duration of the covid-19 pandemic or until otherwise determined by BM]. You may use, download and print the article for any lawful, non-commercial purpose (including text and data mining) provided that all copyright notices and trade marks are retained. 